Romadhan, A. N., \& Purwandari, E. (2020). Peran sanggar regoling ma'rifat dalam penanaman karakter pada anak di era digital. Indigenous: Jurnal Ilmiah Psikologi, 5(1). 67-79. doi: https://doi. org/10.23917/indigenous.v5i1.11144

\title{
Peran Sanggar Regoling Ma'rifat dalam Penanaman Karakter Pada Anak di Era Digital
}

\author{
Ardian Nur Romadhan ${ }^{1}$, Eny Purwandari ${ }^{2}$
}

Magister Sains Psikologi, Universitas Muhammadiyah Surakarta ${ }^{1,2}$ ardian.romadhan@yahoo.com ${ }^{1}$, eny.purwandari@ums.ac.id ${ }^{2}$

\begin{abstract}
Abstrak. Penelitian bertujuan untuk mengetahui peran, harapan, dan tantangan dalam penanaman karakter anak di era digital berbasis Agama Islam pada Sanggar Belajar Anak: Sanggar Regoling Ma'rifat di Desa Carikan, Kecamatan Juwiring, Kabupaten Klaten. Penelitian ini merupakan studi kasus model prosedural bersifat deskriptif. Sumber data berasal dari narasumber, aktivitas, dan dokumen. Teknik pengumpulan data yang digunakan observasi, wawancara dan pemeriksaan dokumen. Data dianalisis secara deskriptif kualitatif yaitu menggunakan analisis interaktif. Hasil penelitian menunjukan peran Sanggar Regoling Márifat di era digital dalam bentuk penanaman karakter pada anak berupa karakter religius dengan pondasi perangai yang diaplikasikan dari Agama Islam, yaitu akhlaq al-karimah yang sesuai dengan tuntunan Alquran dan Hadis. Harapan di era digital berupa penyelarasan aktualisasi anak yang berteknologi dan bertataterpuji (akhlaq mahmudah). Pada tatakelola ini norma agama dan kemajuan teknologi dapat bersinergi dan berdaya guna untuk masa depan yang menyejahterakan dan penuh harapan. Sementara itu, tantangan di era digital berupa menjaubkan perangai tercela (akhlaq madzmumah) dari coping perilaku negatif media teknologi digital seperti: cyberbullying (dzalim), selfie dengan niat (riya \& ujub), cyberwar (ghibah), penyampaian informasi hoax (dusta) dan sebagainya. Simpulan: akhlak yang mulia dan terpuji merupakan kunci dari penanaman karakter religius di Sanggar Regoling Márifat sehingga serangkaian perangai tersebut akan terpatri pada diri anak sanggar. Sedangkan menjaubkan perangai tercela merupakan tantangan dalam penanaman karakter seorang Muslim dan Mukmin dalam berteknologi secara tepat guna, beradab dan berbudi pekerti luhur. Penelitian ini berimplikasi sebagai example-model dalam penanaman karakter pada anak dengan nilai keIslaman yang kaffah dan mempromosikan pendidikan karakter religius berbasis Agama Islam terhadap anak sebagai trend-model penanaman pendidikan karakter di era digital.
\end{abstract}

Katakunci: era digital; karakter; sanggar belajar anak

Abstract. This research aims to find out the role, expectations and challenges in the cultivation of children's character in the digital era based on Islamic religion in the Children Learning Studio: Regulating Ma'rifat Studio in Carikan Village, Juwiring District, Klaten Regency. This research is a case study of a descriptive procedural model. Sources of data come from sources, activities, and documents. Data collection techniques used observation, interviews and document checks. Data were analyzed descriptively qualitatively using interactive analysis. The results showed the role of the Sanggar Regoling Ma'rifat in the digital era in the form of character planting in children in the form of religious characters with the foundation of temperament applied from Islam, namely akhlaq al-karimah in accordance with the guidance of the Koran and Hadith. Hopes in the digital age are in the form of harmonizing the actualization of children who are technologically and admirable (akhlaq mahmudah). In this governance 
religious norms and technological progress can work together and be efficient for a prosperous and hopeful future. Meanwhile, the challenges in the digital age are to distance the despicable behavior (akhlaq madzmumah) from coping with the negative behavior of digital technology media such as: cyberbullying (dzalim), selfies with intentions (riya \& ujub), cyberwar (ghibah), delivery of hoax information (lies) and lies so. Conclusion: noble and praiseworthy character is the key to cultivating religious character in the Regoling Ma'rifat Studio so that a series of temperament will be imprinted on the studio's children. While keeping away despicable temperament is a challenge in instilling the character of a Muslim and a believer in appropriate, civilized and virtuous character technology. This research has implications as an example-model in the cultivation of character in children with Islamic values and promotes religious character education based on Islamic religion towards children as a trend-models for planting character education in the digital era.

Keywords: digital era; character; children's learning center

\section{PENDAHULUAN}

Kemunculan era digital ditandai dengan adanya perkembangan keilmuan di bidang Ilmu pengetahuan dan teknologi (IPTEK), bersamaan dengan hal itu adanya akses jaringan internet yang cepat dan mudah dalam menjangkau segala lini semakin membuat teknologi ini menjadi alternatif pengganti untuk mendapatkan atau memberikan informasi yang dibutuhkan oleh individu. Hal ini merefleksikan bahwa terd-apat adanya pergeseran budaya yang berbeda dari serba manual menjadi budaya dengan segala sesuatu yang digantikan dengan cara digital. Kemajuan dalam bidang IPTEK ini memberikan manfaat bagi individu dalam menjalankan segala aktifitasnya. Vasile (2012) mengatakan masyarakat informasi merupakan bagian dari hadirnya teknologi yang memfasilitasi banyak bidang kegiatan. Berkat kemajuan teknologi ini, individu memiliki pola pikir global dan mengalami perubahan gaya hidup. Semua perubahan pola ini terjadi dalam waktu yang singkat, hal inilah yang disebut dengan era digital.

Fenomena sosial yang terjadi pada era digital menunjukan bahwa saat ini generasi usia muda hidup berdampingan dengan zaman di mana teknologi digital menjadi bagian dalam kehidupan dan sangat mudah diakses. Anak dan remaja masa kini mereka telah mendapat julukan dengan sebutan yang khas, seperti: Pemuda Digital, Digital Natives, Generasi Millenial, Gen Net, Generasi Google, Generasi MySpace, Gen Y, Generasi Z, Generasi I atau disebut juga dengan Generasi Internet (Calara, 2020; Herther, 2009; Rutherford et al., 2011). Generasi inilah yang hidup di era digital, era yang berbeda dari generasi sebelumnya yang hidup secara bersama, berinteraksi dan bersosialisasi dalam menjalin komunikasi sosial yang nyata di dalam kelompok masyarakat. Sedangkan kehidupan di era ini membawa generasinya seperti hidup sendirian tanpa memerlukan sosialisasi nyata dengan orang lain. Teknologi merupakan bahasa di era ini, sehingga kita harus memanfaatkannya terutama dalam menangani generasi muda yang cukup terampil bermedia tanpa perlu seorang yang mengajarkannya (Miniawi \& Brenjekjy, 2015) Usia muda merupakan masa pertumbuhan yang selalu dekat dengan aktualisasi diri dalam pengembangan kognitif, afektif, dan psikomotorik. Peneliti melihat menariknya fenomena penelitian ini dalam penanganan penanaman pendidikan karakter pada anak usia muda di era digital.

Secara langsung maupun tidak langsung teknologi memiliki dampak positif pada bidang sosial dan lingkungan tanpa bergantung pada deterministik (Gunderson, 2018). Dampak positif ini telah banyak dirasakan manfaatnya. Namun di sisi lain teknologi tidak pernah dapat menanamkan nilai-nilai disiplin, ketepatan waktu dan banyak hal penting lainnya yang dapat dikomunikasikan 
oleh seorang guru kepada anak didik (Miniawi \& Brenjekjy, 2015). Menurut Ameliola dan Nugrah, (2013) dampak positif dari adanya teknologi bagi anak adalah memudahkan anak mencari sumber belajar dan menjadi media bagi anak untuk dapat mengasah kreativitas maupun kecerdasannya, sedangkan dampak negatifnya menyebabkan anak menjadi lupa diri, malas untuk bergerak dan melakukan aktivitas, sehingga mengganggu perkembangan kognitif dan afektif anak.

Dampak negatif tersebut perlu disikapi dengan melibatkan ranah pendidikan non-formal atau pembelajaran diluar sekolah bagi anak. Untuk menghadapi tantangan global, pendidikan merupakan pusat keunggulan dalam mempersiapkan karakter manusia yang berkompeten (Rokhman et al., 2014). Ada empat pilar pendidikan di era digital, yaitu: Learning to know, kognisi mendasari behavioral artinya proses belajar merupakan pemenuhan untuk kognisi, yang mana akan terefleksi pada perilaku anak; Learning to do, anak dapat mengaplikasikan pengetahuan dari hasil belajarnya di kehidupan nyata dan memiliki manfaat bagi diri sendiri maupun orang lain; Learning to be, belajar menjadi harapan bagi diri sendiri dan harapan bagi lingkungan masyarakat; Learning to live together, belajar hidup bersama, bersosial, berinteraksi dan berkontribusi kepada masyarakat (Delors, 2013; Nurhayati, 2011).

Pendidikan yang diberikan terhadap anak harus disesuaikan dengan perkembangan psikologisnya. (Widiana, 2009). Piaget dalam teori perkembangan kognitif menjelaskan bahwa selama masa usia 7 hingga 12 tahun individu mengalami tahap perubahan dari konsep berpikir logis yang masih terbatas pada benda-benda konkret secara oprasional ke konsep berpikir formal dengan penalaran dan logika secara oprasional. Banyak hal yang mempengaruhi tingkatan perkembangan kognitif individu antara lain adalah kedewasaan, pengalaman fisik, pengalaman logika, transmisi sosial dan pengaturan sendiri (ekuilibrasi) (Ibda, 2015; Iqbal, 2015). Pendidikan pada dasarnya merupakan suatu proses belajar untuk perkembangan kognitif individu. Pada perkembangan transmisi sosial proses pertambahan konstruksi kognitif berasal dari pendidikan yang menyerap unsur-unsur pengetahuan dari luar diri individu. (Nurhayati, 2011). Pada pendidikan berbasis masyarakat, tindakan dilakukan dengan kerja sama secara kolektif oleh masyarakat sendiri dalam upaya memvalidasi pengetahuan dan penggunaan pengetahuan. Masyarakat pada konteks ini memupuk kapasitas perubahan sosial secara demokratis melalui media pendidikan.

Pendidikan berbasis masyarakat yang dikelola oleh sanggar belajar anak "Sanggar Regoling Ma'rifat bertujuan” bertujuan untuk mengubah pandangan anak-anak tentang sulitnya belajar, sehingga mereka akan lebih senang dan mudah dalam belajar. Ilmu akademik dan ilmu agama hendaknya diselaraskan, maka selain pembelajaran ilmu akademik, sanggar ini juga mengedepankan pendidikan ilmu keagamaan Islam dalam penanaman karakter anak sanggarnya. Dengan penyelarasan antara ilmu akademik dan ilmu agama ini insyAllah nantinya menjadi anak yang memiliki akhlak mulia dan cerdas. Sanggar ini didirikan pada tanggal 20 Januari 2016 dan memiliki arti nama yaitu pintu masuk menuju perbuatan yang baik dan bijakasana.

Senada dengan tujuan Sanggar Regoling Ma’rifat, Islam sangat menaruh perhatian tentang berbagai penguatan dalam peningkatan kompetensi pendidikan generasi muda dalam sektor formal maupun non-formal pada segala aspek lini kehidupan (K \& Sugirma, 2017). Nabi Muhammad saw, telah mengingatkan kita tentang istimewanya generasi muda, yakni: "Aku wasiat-amanatkan kepadamu terhadap pemuda-pemuda (angkatan muda) supaya bersikap baik terhadap mereka. Sesungguhnya hati dan jiwa mereka sangat halus. Maka sesungguhnya Tuhan mengutus aku membawa berita gembira dan membawa peringatan. Angkatan mudalah yang menyambut dan menyokong aku, sedangkan angkatan tua menentang dan memusubi aku".

Karakter merujuk pada hubungan antara sikap (attitude) dan perilaku (behavior) dari nilainilai dasar yang berada di hati individu, tindakan dan sikap tersebut berasal dari dorongan langsung 
oleh otak, terbentuk baik karena pengaruh dari lingkungan, baik dari lingkungan keluarga, sosial masyarakat maupun dari lingkungan luar lainnya (Ekawati et al., 2018; Pane \& Patriana, 2016; Rusydiyah, 2014). Pengembangan karakter merupakan interaksi dinamis antara faktor-faktor determinan, yaitu: pengaruh internal dan pengaruh eksternal. Pengaruh internal didapat dari dalam diri individu. Sedangkan pengaruh eksternal yang mempengaruhi perilaku individu didapat dari pendidikan, keluarga, sosial, dan budaya (Agboola \& Tsai, 2008). Sektor pendidikan harus dipromosikan dengan strategi yang lebih agresif, untuk menghadapi ancaman dampak negatif pada pendidikan karakter dari pengaruh media dan internet di era digital (Lee et al., 2013). Pendidikan karakter merupakan masalah yang kompleks dan harus dimulai sedini mungkin (Cengelci 2015, (Çengelci, 2015; Mei-Ju et al., 2014; Tiwari, 2020). Pendidikan karakter yang baik harus melibatkan moral knowing, moral feeling, \& moral action (Hindun, 2014; Izzati et al., 2019; Permono, 2013).

Ada banyak identifikasi nilai karakter, yaitu: religius, kerja keras, jujur, toleransi, mandiri, dst. Potensi afektif inilah yang harus ditanamkan kepada anak-anak, namun untuk menghadapi era digital seperti saat ini, Sanggar Regoling Ma'rifat lebih mengutamakan konsep pendidikan berlandaskan penanaman karakter religius berbasis agama Islam dengan semangat ruhaniyah dan insaniyah yaitu pola hubungan antara aspek vertikal (hablum min Allah) dan aspek horizontal (hablum min $A n-N a a s)$. Proses internalisasi nilai Ketuhanan dalam pendidikan agama Islam terjadi secara bertahap sesuai dengan proses perkembangan manusia yang membentuk kepribadian utuh dan menampakkan wataknya dalam perilaku amal perbuatan (Pusfiyaningsih, 2012) Pendidikan agama memiliki peran terutama dalam pembentukan moral, didalam agama sesungguhnya sudah terdapat muatan pendidikan karakter dimana setiap ibadah yang dilakukan dapat membentuk kognitif, afektif dan konatif manusia (Ene \& Barna, 2015; Suhardini et al., 2020; Taufik, 2020; Yuwono, 2011). Karakter religius merupakan perwujudan sikap dan perilaku yang taat dalam menjalankan ajaran agama, karakter ini memiliki peran penting dalam membangun kematangan berkarakter bagi anak dan menjadi pondasi dalam menumbuhkan kebiasaan anak dalam praktik beragama yang toleran terhadap orang lain, dan hidup rukun dengan agama lain dalam kehidupan seharihari (Ekawati et al., 2018; Fahmy et al., 2015). Manfaat religius/spiritualitas pada diri individu adalah menciptakan gaya hidup yang memiliki sikap positif, mampu mengontrol sikap maupun perilaku dan mengarahkan diri untuk terhindar dari sifat negatif (Suseno, 2013). Diharapkan melalui internalisasi karakter ini, para anak sanggar insyAllah akan tumbuh menjadi "anak yang sholeh, sholehah, cerdas, cinta damai, bertanggung jawab, cinta NKRI dan memiliki serangkaian akblak mulia" (kutipan wawancara langsung dengan penanggungjawab sanggar berinisial S tanggal 9 September 2018).

Peneliti melakukan studi kasus pada sanggar belajar anak di desa Carikan, Kec. Juwiring, Kab. Klaten, yaitu Sanggar Regoling Ma’rifat. Sanggar ini dibentuk sebagai wadah komunitas dalam pendidikan berbasis masyarakat, dan bimbingan dalam belajar khususnya pembelajaran bahasa Inggris \& Matematika yang diselenggarakan secara gratis untuk masyarakat sekitar. Sanggar Regoling Ma’rifat dipilih sebagai lokasi penelitian karena sanggar ini mengedepankan pendidikan ilmu keagamaan Islam dalam penanaman karakter pada anak sanggarnya.

Sebagai penuntun penelitian, dirumuskan pertanyaan penelitian bagaimanakah peran Sanggar Regoling Márifat dalam penanaman karakter pada anak dan apa saja harapan maupun tantangannya di era digital. Tujuan penelitian ini adalah untuk mengetahui peran, harapan dan tantangan dalam penanaman karakter anak di era digital berbasis Agama Islam pada Sanggar Belajar Anak: Sanggar Regoling Ma’rifat. 


\section{METODE}

Penelitian ini menggunakan pendekatan kualitatif dengan bentuk studi kasus. Teknik pengumpulan data yang digunakan adalah observasi, wawancara dan pemeriksaan dokumen. Sumber data dalam penelitian ini mengunakan narasumber, aktifitas, dan dokumen. Pengumpulan data tersebut dilakukan selama tanggal 30 Agustus 2018 s/d 22 September 2018. Subjek narasumber dalam penelitian ini sudah melalui persetujuan (informed consent) berjumlah 5 informan terdiri atas 1 orang penanggung jawab sanggar, 1 orang ustadz sanggar, 1 orang miss sanggar (pengajar ilmu akademik), dan 2 anak sanggar dengan kriteria pendidikan SD. Aktifitas, berupa pengamatan proses penanaman karakter religius yang dilakukan pada saat proses pembelajaran berlangsung pada hari senin, kamis dan sabtu. Sedangkan dokumen, berupa arsip tertulis yang berhubungan dengan penanaman karakter religius, tujuan \& fungsi sanggar, visi misi, foto-foto kegiatan, dan dokumen lainnya yang relevan terhadap kasus yang menjadi obyek penelitian ini.

Teknik analisis data yang digunakan untuk mengolah data yang diperoleh dalam penelitian ini adalah menggunakan analisis deskriptif kualitatif dengan mengorganisasikan data dan mengelompokkan berdasarkan indikator penanaman karakter religius berbasis agama Islam. Pada penelitian ini pengecekan dilakukan antara data hasil wawancara dengan data hasil pengamatan dan hasil pemeriksaan dokumen.

Data dianalisis dengan model prosedural bersifat deskriptif dan untuk menganalisis data yang terkumpul mengunakan analisa interaktif, berupa pengumpulan data, penyajian data dan penarikkan kesimpulan.

\section{HASIL DAN PEMBAHASAN}

Sasaran utama dari pendidikan berbasis masyarakat di desa carikan yang dikelola oleh Sanggar Regoling Ma'rifat adalah untuk memperkaya ilmu pengetahuan anak melalui pembelajaran di komunitas, sehingga insyAllah anak akan menjadi generasi yang berakhlak mulia dan cerdas. Untuk terwujudnya generasi yang berakhlak mulia dan cerdas ini tatakelola pelaksanaan pendidikan di Sanggar Regoling Ma’rifat dilakukan dengan memberikan penanaman karakter religius berbasis agama Islam terlebih dahulu sebagai pondasi awal dan diselaraskan dengan pendidikan ilmu akademik. Penanaman karakter religius yang ditanamkan pada anak sanggar secara eksplisit yaitu, dengan pola hubungan antara hablum min Allah dengan semangat ruhaniyah (Islam merupakan jalan hidup yang bersumber dari \& untuk Allah Subhanahu wa ta'ala) dan hablum min An-Naas dengan semangat insaniyah (Islam merupakan agama yang diturunkan untuk manusia), sehingga tindakan, sikap (attitude) dan perilaku (behavior) keseharian anak berorientasi pada nilai keIslaman yang kaffah. Seperti petikan wawancara singkat dengan ustadz sanggar berinisial SM berikut ini: "bilih anak-anak saget ninda'ake hablum min Allah lan hablum min An-Naas (anak-anak dapat mengimplementasikan hablum min Allah \& hablum min An-Naas)" (wawancara langsung tanggal 20 September 2018).

Sanggar Regoling Ma'rifat memiliki 3 program kerja (1) Bidang Pendidikan: pembelajaran bahasa Inggris (Fun Learning, Conversation \& speech, vocabulary, english game), study tour, ketrampilan dan pembelajaran matematika. (2) Bidang Keagamaan: BTQ, Tahfidz, Islamic Story dan Game. (3) Bidang Sosial: Baksos (Giving Habbit), Kerja Bakti (Fun Cleaning) dan jalan sehat. Selain program tersebut, Sanggar Regoling Ma'rifat juga memiliki beberapa adab sanggar yang khas diantaranya Adab Belajar, Adab Salam, Adab Kesantunan Bahasa, Adab Penyuluhan, Adab Reward, Adab Infaq, dan Adab Cleaning. 


\section{Adab Belajar}

Pembelajaran berbasis masalah (problem based learning) menjadi adab pembelajaran yang diterapkan di Sanggar Regoling Ma’rifat. Adab belajar ini memiliki tendensi dalam melibatkan anak sanggar untuk aktif dalam proses pembelajaran, misalnya seperti pemberian tugas dalam bentuk case setelah sebelumnya anak sanggar mendapat materi belajar yang disampaikan oleh ustadz atau miss sanggar. Pembelajaran ini menjadi hal yang menarik dan menyenangkan bagi anak sanggar dalam mengikuti pembelajaran di sanggar. Selain itu dalam memberikan motivasi Sanggar Regoling Ma'rifat lebih mengedepankan pemberian teladan dan menerapkan pembiasaan bagi anak sanggarnya. Misalnya, ketika sudah tiba waktunya shalat, maka seluruh aktivitas dihentikan dan segera memenuhi panggilan Allah Subhanahu wa ta'ala untuk menjalankan ibadah shalat.

\section{Adab Salam}

Sebagai salah satu bentuk kecintaan antar sesama muslim Sanggar Regoling Ma’rifat menanamkan pembiasaan pada anak dalam mengucapkan dan menjawab salam, selain untuk bertegur sapa salam juga merupakan sebuah doa. Dengan menjalankan sunnah Rasulullah a'laihi wa sallam ini insyAllah menjadi amalan mulia bagi seorang muslim dan mu'min. Contoh dalam pela ksanaanya adalah menjabat tangan dan mengucap salam ketika bertemu atau berpamitan dengan ustadz maupun orang yang lebih tua disanggar.

\section{Adab Kesantunan Bahasa}

Dalam komunikasi bahasa Sanggar Regoling Ma’rifat menerapkan prinsip kesantunan berbahasa yang baik dan mencegah kemungkaran. Disebutkan dalam Al-Quran Surah An-Nisa, yaitu: "Allah tidak menyukai perkataan buruk, (yang diucapkan) secara terus terang kecuali oleh orang yang dizalimi. Dan Allah Maha Mendengar, Maha Mengetahui" (QS. An-Nisa: 148). Pada ayat AlQuran tersebut dijelaskan bahwa perkataan yang buruk merupakan hal yang tidak di sukai oleh Allah Subhanahu wa ta'ala. Perkataan buruk sendiri berupa penggunaan bahasa yang kurang baik, tidak santun, dan tidak beradab (dapat menyakiti sesama manusia). Contoh perilaku kesantunan berbahasa didalam sanggar, ketika sesama anak sanggar sedang berselisih paham dibiasakan untuk segera saling mengucapkan maaf tanpa adanya perkataan buruk. Memaafkan sendiri merupakan komunikasi yang mewakili seseorang memiliki pribadi akhlak mulia.

\section{Adab Penyuluhan}

Proses pemberian bimbingan atas solusi dari penyelesaian masalah yang dimiliki oleh anak sanggar, baik berupa permasalahan dalam belajar maupun permasalahan anak lainnya. Misalnya, anak sanggar yang memiliki kesulitan dalam Baca Tulis Al-Quran, menghafal surat pendek, dan/ atau dalam mengerjakan PR/tugas dari guru di sekolah, hal tersebut dapat di komunikasikan di sanggar dan menjadi bahan diskusi bersama. Seperti petikan wawancara singkat yang dilakukan dengan salah satu anak sanggar berinisial AW berikut ini: "aku seneng belajar neng sanggar .. isoh ngaji karo garap PR (saya senang belajar disanggar bisa ngaji \& mengerjakan PR)" (wawancara langsung tanggal 3 September 2018).

\section{Adab Reward}

Anak sanggar yang rajin dalam mengikuti pembelajaran di sanggar atau memiliki prestasi di sekolah, akan mendapat reward atau hadiah sebagai reinforcement. Uniknya di sanggar ini Punishment diberikan juga dalam bentuk reward namun dengan jumlah yang berbeda. Disini nilai yang ditanamkan pada anak adalah "anak yang rajin akan mendapat hadiah yang lebih banyak 
daripada anak yang kurang rajin" (kutipan wawancara langsung dengan miss sanggar berinisial ED tanggal 30 Agustus 2018).

\section{Adab Infaq}

Adab infaq itu sendiri dasar pemikirannya bukan sanggar menginginkan uang dari anak sanggar, melainkan untuk mengedukasi pada anak akan keutamaan dari berinfaq yangmana menghindarkan anak dari sifat kikir, mengajarkan pada anak untuk senantiasa melakukan perbuatan yang mulia (dermawan), menanamkan sikap ikhlas, beriman, dan bertakwa pada anak. Selain itu agar supaya timbul rasa tanggung jawab dari dalam diri anak sanggar. Tanggung jawab dalam kehadiran dan keikut sertaan dalam pembelajaran disanggar. Pengelolaan infaq ini sendiri kegunaannya dikembalikan kepada pembelajaran pada anak sanggar itu sendiri "jadi dari anak sanggar ya ta ... untuk anak sanggar" (kutipan wawancara langsung dengan penanggungjawab sanggar berinisial S tanggal 9 September 2018). Misalnya, difungsikan pada kegiatan pembelajaran di luar sanggar study tour.

\section{Adab Cleaning}

Agama Islam menjunjung tinggi akan kebersihan, baik dalam bentuk batiniyah maupun dalam bentuk lahiriyah. Salah satu firman Allah tentang kebersihan disebutkan dalam Al-Quran Surah Al-Muddassir, yaitu: "Dan pakaianmu bersihkanlah. Dan tinggalkanlah segala (perbuatan) yang keji" (QS. Al-Muddassir: 4-5). Firman tersebut menunjukan bahwa kebersihan merupakan entitas yang dicintai oleh Allah Subhanahu wa ta’ala. Dalam adab cleaning Sanggar Regoling Ma'rifat melibatkan anak sanggar secara langsung. Misalnya, sebelum dan sesudah mengikuti pembelajaran anak sanggar dibiasakan untuk membersihkan tempat belajar seperti menata meja, menyapu dan lain sebagainya. Dengan pembiasaan adab sanggar yang khas ini secara sistematis akan menjadi norma dan aturan dalam berperilaku anak yang didasarkan pada nilai-nilai luhur agama Islam.

Empat pilar pendidikan di era digital. Pada pilar Learning to know, sikap dan perilaku yang tercermin dari anak sanggar seperti bersegera dalam meminta maaf ketika melakukan kesalahan, mengucap salam ketika bertemu atau berpamitan dan lain sebagainya. Hal tersebut terbentuk secara sistematis dari pemenuhan afektif anak sanggar dalam proses penanaman nilainilai \& norma religius. Pilar Learning to do, melalui adab belajar pembiasaan. Misalnya, ketika mendengar kumandang adzan anak sanggar dibiasakan untuk segera melaksanakan ibadah Shalat. Hal ini merupakan aplikasi dari proses hasil penanaman karakter religius berupa rukun islam dalam perkara mendirikan shalat. Sedangkan pada pilar Learning to be, anak sanggar belajar menjadi harapan bagi diri sendiri dengan dibekalinya ilmu akademik dan ilmu agama Islam dengan pondasi yang tertanam melalui pembelajaran BTQ maupun Tahfidz. Sedangkan dalam kegiatan di bidang sosial masyarakat pilar Learning to live together tergambar pada kegiatan Giving Habbit maupun Fun Cleaning yang dilakukan oleh anak sanggar. Kegiatan tersebut mengajarkan anak untuk bersosialisasi dan berkontribusi secara nyata pada lingkungan masyarakat.

Harapan dan tantangan di era digital dalam penanaman karakter religius di Sanggar Regoling Ma’rifat berupa harapan kepada anak sanggar bahwa karena sudah dibekali dengan akhlak mulia dan cerdas, maka ketika mereka berinteraksi di media teknologi digital harus menjujung tinggi nilai etika Islam dan memliki attitude baik yang mengarah pada sikap keterpujian, sehingga mereka mampu memfilter, memilih, memilah mana yang baik dan menjauhi perkara yang tidak bermanfaat yang menjurus kedalam perbuatan yang di benci Allah Subhanahu wa ta'ala. Seperti petikan wawancara singkat yang dilakukan dengan penanggungjawab sanggar berinisial $S$ berikut ini: "karena dia punya akhlak mulia ya ta ... dan dia cerdas dia bisa memilih dan memilah oo... ini 
hoax oo... ini salah atau bahkan kalo katakanlah ragu gak ngerti gak usah disebarkan tadi dengan sendirinya dia akan memfilter diri .. apa filter dia karena akblak dan kecerdasan dia" (wawancara langsung tanggal 9 September 2018). Tentunya selain memiliki nilai-nilai keterpujian diharapkan anak sanggar juga mampu menggunakan dan memanfaatkan teknologi digital secara tepat guna, yangmana dapat membawa kesejahteraan sekaligus kebermanfaat bagi umat maupun masyarakat sekitar dan menjadikan teknologi digital sebagai wahana silaturahmi, bermuamalah dan menjaga ukhuwah. Dalam hal ini upaya bertahap yang dilakukan oleh Sanggar Regoling Ma'rifat secara berkesinambungan dalam menghadapi era digital yaitu, berupa penyediaan perangkat komputer, saat ini sanggar sudah memiliki dua perangkat komputer untuk difungsikan sebagai pengenalan teknologi secara langsung kepada anak sanggar. Sedangkan tantangannya berupa membendung perangai negatif dari arus kemajuan zaman yang begitu pesat dengan cara membentengi diri dari meniru atau mencontoh sikap dan perilaku tercela yang dibawa bersamaan dengan majunya teknologi digital.

Fungsi dan manfaat adanya sanggar bagi komunitas, yaitu: meningkatkan kemampuan anak-anak dalam berbahasa Inggris; anak-anak lebih mudah dalam belajar bahasa Inggris dan Matematika; meningkatkan kemampuan anak-anak dalam membaca Al-Quran; meningkatkan kemampuan anak-anak dalam menghafal Al-Quran minimal juz 30; Anak-anak memahami dan mengerti akan Rukun Islam dan Rukun Iman.

Peran sanggar dalam penanaman karakter pada anak di era digital berupa akhlaq alkarimah, penanaman akhlak yang mulia atau baik. Anak ditanamkan memiliki sikap akhlak mulia dalam bersikap dan bertingkahlaku serta santun dalam berbahasa melalui tuntunan dalam Al-Qur'an dengan pembelajaran Tahfidz maupun bersungguh-sungguh dalam membaca atau menghafal Al-Quran dan dengan tuntunan dalam Hadits dengan pembelajaran Islamic Story. Pada era yang serba digital ini banyak media teknologi digital yang difungsikan untuk kemudahan dalam berinteraksi. Namun penggunaan media teknologi digital yang tidak bijak di zaman ini membuat sebagian penggunanya memfungsiakan dengan kurang tepatguna. Disebutkan dalam penelitian (Herwanto \& Sarah, 2015; Nugroho, 2017; Pierri \& Ceri, 2019) bahwa beberapa pengguna telah menyalahgunakan media digital sebagai lahan menyebar berita bohong dan melakukan penipuan, konsekuensi dari penyampaian informasi hoax dapat menyebabkan putusnya hubungan pertemanan, ketidak harmonisan didalam keluarga, dan lain sebagainya. Hal tersebut menggambarkan bahwa adanya pengaruh negatif dalam bentuk sifat tercela (akhlaq madzmumah) dari adanya kemajuan teknologi digital. Seseorang yang memiliki akhlaq al-karimah dalam pembawaan interaksinya insyAllah akan santun, menjauhi segala perangai tercela dan disenangi oleh sesama.

Pengaruh positifhadirnya teknologi digital pada anak salah satunya adalah dapat memberikan dampak pada perkembangan kognisi anak karena adanya beragam aplikasi digital dengan interface yang menarik sebagai sarana belajar, sehingga membuat anak lebih senang dan bersemangat dalam belajar (Ameliola \& Nugraha, 2013). Penyelarasan aktualisasi anak dan teknologi digital harus dilakukan dengan upaya terkontrol secara bertahap, terencana, dan berkesinambungan, sehingga teknologi digital dapat dimanfaatkan secara maksimal dalam mengakses berbagai aktivitas. Aktivitas kehidupan yang menuju pada sikap dan perilaku yang jujur, sabar, bersyukur, ikhlas, rendah hati, qana'ah, dll., sehingga pada tatakelola ini norma agama dan kemajuan teknologi digital dapat bersinergi dan berdaya guna. Dengan demikian, maka terwujudlah generasi yang berteknologi dan bertataterpuji (akhlaq mahmudah) untuk masa depan yang mensejahterakan dan penuh harapan.

Tantangan nyata pada anak di era digital semakin kompleks termasuk pengaruhnya terhadap karakter yang dimiliki anak. Pengaruh global maupun budaya yang masuk didalamnya berpotensi 
membawa perubahan pada setiap sisi karakter anak. Dengan kemajuan teknologi digital, siswa menemukan metode bullying baru, bahwa sebagian besar siswa di kelas 6, 7, 10, dan 11 terlibat dalam cyberbullying dan cyberbullying tidak terbatas pada ruang kelas atau sekolah (Ansary, 2020; Redmond et al., 2020; Wade \& Beran, 2011). Menghabiskan waktu berjam-jam di layar ponsel atau komputer dapat mempengaruhi kemampuan untuk fokus, dan ada beberapa perubahan perilaku penggunaan media sosial yang harus diamati, seperti selfie, cyberwar, belanja online, personalisasi pengguna, dan budaya bersama (Adorjan, 2019; Miniawi \& Brenjekjy, 2015; Mulawarman \& Nurfitri, 2017). Hal ini menggambarkan bahwa sifat tercela (akhlaq madzmumah) bisa merasuki anak jika terlalu sering berinteraksi di media teknologi digital tanpa bimbingan dan pengawasan. Perwujudan behavior dari cyberbullying, selfie, cyberwar dan sebagainya merefleksikan sifat seperti sombong (takabur), dengki, dzalim, ghadhab, ghibah, riya, ujub, dusta, dll. Tantangan di era digital inilah yang harus disikapi dengan penanaman karakter religius berbasis agama Islam.

\section{SIMPULAN}

Dari uraian hasil dan pembahasan, diperoleh kesimpulan bahwa peran Sanggar Regoling Ma’rifat di era digital dalam bentuk penanaman karakter religius pada anak dengan pondasi perangai yang diaplikasikan dari Agama Islam, yaitu akhlaq al-karimah yang sesuai dengan tuntunan Qur'an dan Hadits. Harapan di era digital berupa penyelarasan aktualisasi anak yang berteknologi dan bertataterpuji (akhlaq mahmudah) dalam bersikap maupun berperilaku. Sementara itu tantangan di era digital berupa menjauhkan perangai tercela (akhlaq madzmumah) dari coping perilaku negatif media teknologi digital seperti: cyberbullying (dzalim), selfie dengan niat (riya \& ujub), cyberwar (ghibah), penyampaian informasi hoax (dusta) dan sebagainya. Singkatnya, akhlak yang mulia dan terpuji merupakan kunci dari penanaman karakter religius di Sanggar Regoling Ma’rifat, sedangkan menjauhkan perangai tercela merupakan tantangan dalam penanaman karakter seorang Muslim dan Mu'min dalam berteknologi secara tepat guna, beradab dan berbudi pekerti luhur.

Penelitian ini berimplikasi sebagai example-model dalam penanaman karakter pada anak dengan nilai keIslaman yang kaffah dan mempromosikan pendidikan karakter religius berbasis Agama Islam terhadap anak sebagai trend-model penanaman pendidikan karakter di era digital.

Mengacu pada temuan-temuan hasil dan pembahasan pada penelitian ini, maka peneliti memberikan saran dalam tatakelola penanaman karakter religus pada anak. Saran untuk pengelola sanggar, disarankan dapat menumbuhkan Digital Resilience pada anak sanggar dan merangkul tokoh masyarakat maupun segenap elemen masyarakat sebagai bentuk berbagi tanggung jawab dalam memberikan pendidikan karakter pada anak. Digital Resilience sebagai cara mengatasi tantangan di era digital (Garista \& Pocetta, 2014; Udwan et al., 2020). Untuk orang tua, disarankan dapat memberikan pengawasan dan pola asuh yang tepat secara langsung terhadap anak. Misalnya, menetapkan scheduling waktu anak dalam bermain, belajar dan berinteraksi dengan teknologi digital. Cara mendidik anak di era digital dengan mengaplikasikan pola asuh yang tidak otoriter dengan pengawasan secara terarah dan terpadu langsung dari orang tua sebab anak cenderung tidak suka dipaksa namun lebih menginginkan untuk dibujuk dan dibiarkan (Ameliola \& Nugraha, 2013; Faisal, 2016). Orang tua juga memiliki peran aktif dalam pengasuhan pada pemahaman agama dan melatih kecakapan life skill anak (A'yun et al., 2016). Sedangkan untuk masyarakat disarankan dapat memberikan dukungan sosial secara konkret dalam bentuk pentransferan knowledge, maupun dalam bentuk bantuan moril dan materil. Karena dalam tatalaksananya Sanggar Regoling Ma’rifat masih membutuhkan sarana dan prasarana yang memadai guna mendukung keberlangsungan pendidikan ilmu agama dan ilmu akademik pada anak sanggarnya. 


\section{REFRENSI}

A'yun, Q., Prihartanti, N., \& Chusniatun, C. (2016). Peran orang tua dalam pendidikan anak usia dini (Studi kasus pada keluarga muslim pelaksana homeschooling). Indigenous: Jurnal Ilmiah Psikologi, 13(2). http://journals.ums.ac.id/index.php/indigenous/article/view/2601

Adorjan, M. (2019). Review of Dyer-Witheford, N., \&amp; Matviyenko, S. (2019). Cyberwar and revolution: Digital subterfuge in global capitalism. Security Journal. https://doi. org/10.1057/s41284-019-00186-6

Agboola, A., \& Tsai, K. C. (2008). Bring character education into classroom. European Journal of Educational Research, 1(1), 163-170. https://www.researchgate.net/ publication/283083555_Bring_Character_Education_into_Classroom

Ameliola, S., \& Nugraha, H. D. (2013). Perkembangan media informasi dan tekhnologi terhadap anak dalam era globalisasi. Prosiding The 5th International Conference on Indonesian Studies: "Ethnicity and Globalization," 362-371. https://icssis.files.wordpress.com/2013/09/201302-29.pdf

Ansary, N. S. (2020). Cyberbullying: Concepts, theories, and correlates informing evidence-based best practices for prevention. Aggression and Violent Behavior, 50, 101343. https://doi. org/10.1016/j.avb.2019.101343

Calara, A. N. (2020). Millennials in the information age: Disjuncture amidst technological innovations. Asia-Pacific Social Science Review, 20(1), 205-212. http://apssr.com/ volume-20-no-1/millennials-in-the-information-age-disjuncture-amidst-technologicalinnovations/

Çengelci, T. (2015). Character education of adolescents: A case study of a research center. TED EĞİTIM VE BILIMM, 4O(179). https://doi.org/10.15390/EB.2015.2648

Delors, J. (2013). The treasure within: Learning to know, learning to do, learning to live together and learning to be. What is the value of that treasure 15 years after its publication? International Review of Education, 59(3), 319-330. https://doi.org/10.1007/s11159-013-9350-8

Ekawati, Y. N., Saputra, N. E., \& Periantalo, J. (2018). Konstruksi alat ukur karakter religius siswa sekolah dasar. Psycho Idea, 2, 131-139. file://C:/Users/user/AppData/Local/Temp/33667746-1-SM.pdf

Ene, I., \& Barna, I. (2015). Religious education and teachers' role in students' formation towards social integration. Procedia - Social and Behavioral Sciences, 180, 30-35. https://doi. org/10.1016/j.sbspro.2015.02.081

Fahmy, R., Bachtiar, N., Rahim, R., \& Malik, M. (2015). Measuring student perceptions to personal characters building in education: An Indonesian case in implementing new curriculum in high school. Procedia - Social and Behavioral Sciences, 211, 851-858. https:// doi.org/10.1016/j.sbspro.2015.11.112

Faisal, N. (2016). Pola asuh orang tua dalam mendidik anak di era digital. An-Nisa. https://scholar. google.co.id/scholar?cluster=14934806238947762111\&hl=id\&as_sdt=2005\&sciodt=0,5 
Garista, P., \& Pocetta, G. (2014). Digital resilience: Meanings, epistemologies and methodologies for lifelong learning. Research Gate. https://www.researchgate.net/publication/269628593_ Digital_Resilience_meanings_epistemologies_and_methodologies_for_lifelong_learning

Gunderson, R. (2018). Explaining technological impacts without determinism: Fred Cottrell's sociology of technology and energy. Energy Research \& Social Science, 42, 127-133. https:// doi.org/10.1016/j.erss.2018.03.002

Herther, N. (2009). Digital natives and immigrants: What brain research tells us. Reaearch Gate, 33(6), 14-21. https://www.researchgate.net/publication/29683779-2_Digital_Natives_ and_Immigrants_What_Brain_Research_Tells_Us

Herwanto, H., \& Sarah, F. (2015). Kecemasan terhadap berita hoax ditinjau dari strategi emosi pada millenial mom. JPPP - Jurnal Penelitian dan Pengukuran Psikologi, 4(1), 12-17. https://doi.org/10.21009/JPPP.041.03

Hindun. (2014). The balance of moral knowing, moral feeling, and moral action in langue learning. Proceeding of the Third International Seminar on Languages and Arts, 227-230. file://C:/ Users/user/AppData/Local/Temp/5336-10873-1-SM.pdf

Ibda, F. (2015). Perkembangan kognitif: Teori Jean Piaget. Jurnal Intelektual, 3(1), 27-38. file://C:/ Users/user/AppData/Local/Temp/197-352-1-SM.pdf

Iqbal, H. M. (2015). Cognitive development, educational theories of. In International Encyclopedia of the Social \& Behavioral Sciences (hal. 51-57). Elsevier. https://doi.org/10.1016/B978-008-097086-8.23099-7

Izzati, U. A., Bachri, B. S., Sahid, M., \& Indriani, D. E. (2019). Character education: Gender differences in moral knowing, moral feeling, and moral action in elementary schools in Indonesia. Journal for the Education of Gifted Young Scientists, 7(3), 595-606. https://doi. org/10.17478/jegys.597765

K, A., \& Sugirma. (2017). Tasawuf anak muda: (yang muda yang berhati mulia). Yogyakarta: Deepublish. https://onesearch.id/Record/IOS1.INLIS000000000874915\#description

Lee, C.-Y., Pan, P. J. Der, Liao, C.-J., Chen, H.-Y., \& Walters, B. G. (2013). E-character education among digital natives: Focusing on character exemplars. Computers \& Education, 67, 58 68. https://doi.org/10.1016/j.compedu.2013.02.020

Mei-Ju, C., Chen-Hsin, Y., \& Pin-Chen, H. (2014). The beauty of character education on preschool children's parent-child relationship. Procedia - Social and Behavioral Sciences, 143, 527-533. https://doi.org/10.1016/j.sbspro.2014.07.431

Miniawi, H. El, \& Brenjekjy, A. (2015). Educational technology, potentials, expectations and challenges. Procedia - Social and Behavioral Sciences, 174, 1474-1480. https://doi. org/10.1016/j.sbspro.2015.01.777

Mulawarman, D., \& Nurfitri, A. D. (2017). Social media user behavior and implications based on social-applied psychology perspective. Proceedings of the 9th International Conference for Science Educators and Teachers (ICSET 2017). https://doi.org/10.2991/icset-17.2017.63 
Nugroho, S. (2017). Upaya masyarakat anti fitnah indonesia mengembalikan jatidiri bangsa dengan gerakan anti hoax. Prosiding Konferensi Nasional Peneliti Muda Psikologi Indonesia. https:// www.semanticscholar.org/paper/Upaya-Masyarakat-Anti-Fitnah-Indonesia-Jatidiri-Nugro ho/1d941aaf991531a245432a505747b5052a7e8bc1

Nurhayati,E. (2011).psikologipendidikan inoatif.Yogyakarta: Pustaka Pelaja. http://library.um.ac.id/ free-contents/index.php/buku/detail/psikologi-pendidikan-inovatif-eti-nurhayati-42692. html

Pane, M. M., \& Patriana, R. (2016). The significance of environmental contents in character education for quality of life. Procedia - Social and Behavioral Sciences, 222, 244-252. https:// doi.org/10.1016/j.sbspro.2016.05.153

Permono, H. (2013). Peran orang tua dalam optimalisasi tumbuh kembang anak untuk membangun karakteranakusiadini.https://publikasiilmiah.ums.ac.id/bitstream/handle/11617/3994/02. pdf? sequence $=1 \&$ isAllowed $=y$

Pierri, F., \& Ceri, S. (2019). False news on social Media: A data-driven survey. In Rese.

Pusfiyaningsih, L. Y. (2012). Metode pembiasaan as-sunah dalam pendidikan karakter. https:// publikasiilmiah.ums.ac.id/xmlui/bitstream/handle/11617/1748/A3. Lindayani-UMM $\% 28$ fixed $\% 29$.pdf?sequence $=1$ \&isAllowed $=y$

Redmond, P., Lock, J. V., \& Smart, V. (2020). Developing a cyberbullying conceptual framework for educators. Technology in Society, 60, 101223. https://doi.org/10.1016/j. techsoc.2019.101223

Rokhman, F., Hum, M., Syaifudin, A., \& Yuliati. (2014). Character education for golden generation 2045 (national character building for indonesian golden years). Procedia - Social and Behavioral Sciences, 141, 1161-1165. https://doi.org/10.1016/j.sbspro.2014.05.197

Rusydiyah, E. F. (2014). Character education through the constructivist design of islamic education subject at Elementary School Pembangunan Jaya II in Gedangan Sidoarjo. AL-Ta lim, 21(3), 227. https://doi.org/10.15548/jt.v21i3.108

Rutherford, L., Bittman, M., Brown, J. E., \& Unsworth, L. (2011). 'Digital natives'?: New and old media and children's outcomes. Australian Journal of Education, 55(2), 73-87. https:// www.researchgate.net/publication/259568479_'Digital_natives'_New_and_old_media_ and_children's_outcomes

Suhardini, A. D., Hakam, K. A., \& Hernawan, A. H. (2020). Ineffectiveness of religious education as character education in islamic higher education. Proceedings of the International Conference on Educational Psychology and Pedagogy - "Diversity in Education" (ICEPP 2019). https:// doi.org/10.2991/assehr.k.200130.072

Suseno, M. N. (2013). Efektivitas pembentukan karakter spiritual untuk meningkatkan optimisme terhadap masa depan anak yatim piatu. Jurnal Intervensi Psikologi (JIP), 5(1), 1-24. https:// doi.org/10.20885/intervensipsikologi.vol5.iss1.art1

Taufik, M. (2020). Strategi role of islamic religious education in strengthening character education in the era of industrial revolution 4.0. Jurnal Ilmiah Islam Futur, 20(1), 86-104. https:// 
jurnal.ar-raniry.ac.id/index.php/islamfutura/article/view/5797/3959

Tiwari, S. K. (2020). Identifying character education for research: discourse of relationship with culture, religion and other terms. Studies in Indian Place Names (UGC Care Journal), 40(60), 917-933. file://C:/Users/user/AppData/Local/Temp/5271-Article Text-10047-110-20200326.pdf

Udwan, G., Leurs, K., \& Alencar, A. (2020). Digital resilience tactics of syrian refugees in the netherlands: Social media for social support, health, and identity. Social Media + Society, 6(2), 205630512091558. https://doi.org/10.1177/2056305120915587

Vasile, C. (2012). Digital era psychology - studies on cognitive changes. Procedia - Social and Behavioral Sciences, 33, 732-736. https://doi.org/10.1016/j.sbspro.2012.01.218

Wade, A., \& Beran, T. (2011). Cyberbullying: The new era of bullying. Canadian Journal of School Psychology, 26(1), 44-61. https://doi.org/10.1177/0829573510396318

Widiana, H. S. (2009). Landasan konseptual teoritik psikologik dari berbagai teori inteligensi. Humanitas, 6(1), 56-73. https://pdfs.semanticscholar.org/c705/ d4f218640566c36c7edc51c2ad819cff329c.pdf

Yuwono, S. (2011). Pendidikan karakter melalui agama. https://publikasiilmiah.ums.ac.id/xmlui/ handle/11617/1519 